\title{
Three Civil Rights Fallacies
}

\section{Cass R. Sunstein $\uparrow$}

From the early 1950 s until the present day, three propositions have permeated the arguments of lawyers and others imterested in advancing the cause of civil rights.

The first proposition is that the target of the civil rights movement is discrimination, which is always or usually a product of irrational hatred, fear, or prejudice. In this view, the purpose of civil rights law is to eliminate these forms of irrationahity from the public and private realms.

The second proposition is that the principal function of civil rights law is compensatory. Just as an injured person in a tort action has a right to be made whole, so victims of a history of discrimination (including slavery) are entitled to be put into the place they would have occupied if discrimination had never occurred. Restoration of the status quo ante is a substantial part of the reasoning and rhetoric of civil rights law.

The third proposition is that the judiciary is the appropriate mstitution for the making and enforcement of civil rights law. Reliance on the courts, principally through interpretation of the Constitution, has been a distinctive feature of the civil rights movement since the middle of this century.

In this essay, I argue that these three propositions, which are mutually reinforcing, are fallacies. They misconceive the nature of discrimination and offer prescriptions that are ill-adapted to its elimination. This was so even in the period in which they arose and helped to accomphsh considerable good. But their fallacious character will be especially conspicuous in the last decade of the twentieth and the early decades of the twenty-first century. In this period, the consequences of the fallacies will probably be pernicious.

I do not inean at all to deny that prejudice still plays a major role in many realms of social and economic life, that the history of discrimina-

$\dagger \quad$ Karl N. Llewellyn Professor of Jurisprudence, University of Chicago School of Law and Department of Political Science. B.A. 1975, Harvard University; J.D. 1978, Harvard University. Mary Becker, Anne-Marie Burley, Jon Elster, and Abner Greene provided helpful comments on an earlier draft. For financial support, I am grateful to the James H. Douglas, Jr., Fund for the Study of Law and Government, the Pritzker Family Faculty Fund, and the Jerome F. Kutak Faculty Fund.

Some of this essay unites, draws on, and redirects arguments presented elsewhere: Sunstein, Constitutional Politics and the Conservative Court, AM. ProsPECT, Spring 1990, at 51; Sunstein, The Limits of Compensatory Justice, in NOMOS XXXIII: COMPENSATORY JUSTICE (forthcoming); Sunstein, Why Markets Don't Stop Discrimination, 8 Soc. PHIL. \& POL. - (forthcoming). 
tion is relevant to present problems, or that courts have a continuing role to play in the area of civil rights. But surely these claims are thin and unhelpful in a period when civil rights policy inust concern itself with such probleins as lack of opportunities for education, training, and employment; inadequate housing and health care; vulnerability to and incentives for participation in crime; and teenage pregnancy and singleparent families. For these problems, the traditional claims of the civil rights inoveinent provide at best limited guidance. I conclude with some brief remarks on future directions for civil rights theory and practice.

\section{I}

\section{Fallacy \#1: Discrimination Is Always a Product of Hostility, IrRationality, OR PreJUdice}

In the last generation, it has frequently been suggested that discrininatory behavior is a product of irrational bigotry or hostility. In this account, people treat blacks differently from whites, or women differently froin inen, ${ }^{1}$ because of a form of prejudice. The term "prejudice" is, of course, not self-defining. As conventionally used, the term includes not simply hatred, but also a wide variety of negative judgments about a class of people defined by race or gender.

For present purposes, perhaps we can understand "prejudice" to encompass three sorts of nistakes. ${ }^{2}$ The first consists of a belief that members of a group have certam characteristics when in fact they do not. Here the relevant behef has no basis in reality, and its irrationality is especially conspicuous. The second consists of a belief that many or most members of a group have certain characteristics when in fact only some or a few do. Here the error is an extremely over-broad generalization. The third mistake consists of reliance on fairly accurate groupbased generahzations when more accurate (and not especially costly) classifymg devices are available. Here the members of the group actually have an undesirable characteristic in comparatively large numbers-suppose, for example, that they weigh less, or are less well educated-but it is possible and inore rational to use other, more direct devices to filter out that characteristic. The failure to use those more direct devices reflects a kind of prejudice.

In all these cases, it is reasonable to say that soneone is acting on the basis of irrational prejudice. Indeed, taken together, these cases

1. My focus here is on discrimination against blacks, women, and (to a lesser extent) the handicapped. Of course, other groups are and should be protected by antidiscrimination laws, but at least some of these groups raise distinctive considerations that I cannot discuss here.

2. Cf. Posner, An Economic Analysis of Sex Discrimination, 56 U. CHI. L. REV. 1311, 1318-21 (1989) (discussing the various forms of prejudice that cause sex-based diserimination in the work place); K. Greenawalt, Law and Objectivity ch. 7 (unpublished manuscript) (on file with author). 
probably exhaust the category of prejudice as that term is generally understood. ${ }^{3}$

The theory of civil rights law has often identified "discrimination" with prejudice, and defined an act as discriminatory when it is caused by prejudice. To understand the importance of identifying discrimination with prejudice, it is necessary to understand "discrimination," which is also, of course, a contested concept. For present purposes, I will understand discrimination to include a decision to treat a black person or a woman differently from a white person or a inan, regardless of the motivation.

An influential approach attributes the practice of discrimination to the existence of prejudice or irrationality, $m$ the form of a "taste" for discrimination. ${ }^{4}$ In the workplace, for example, employers might discriminate because they do not like to associate with blacks, woinen, or others. The engine that drives discrimination is employer irrationality or prejudice-not econormic self-interest, narrowly defined as monetary gain. Indeed, economic self-interest conflicts with employers' taste for discrimination. According to a traditional understanding, discriminators will ultimately be driven from the market because they indulge their prejudices at the expense of profits..$^{5}$

This idea has soine truth to it; in some situations, discrimination is costly. But sometimes discrimination is caused by employer practices that stem directly from economic self-interest rather than from the einployer's prejudice or irrationality. ${ }^{6}$ Indeed, discrimination may be fueled by considerations unrelated to the animus of the employer or discriminator. It may, instead, reflect (1) the desires of third parties; (2) statistically accurate generalizations; or (3) the consequences of an unequal status quo for investments in liuman capital and for preference formation. To disregard these points is to produce understandings and

3. Strauss, Discriminatory Intent and the Taming of Brown, 56 U. CHI. L. Rev. 935, 956-59 (1990), suggests that there may be prejudice in the selection of the criteria used to make judgmentsthat is, the decisionmakers might not have selected the same criteria to make the contested decision had the shoe been on the other foot. This might well count as another form of prejudice, and if so, the category is broader than what I have described here. It is difficult, however, to incorporate this notion of prejudice into antidiscrimination law (as Strauss emphasizes), and Strauss' efforts go well beyond conventional understandings of "prejudice" and "discrimination."

4. This view finds its origins in G. BECKER, THE ECONOMics of DisCrimination 14 (2d ed. 1971).

5. But see Akerlof, The Economics of Caste and of the Rat Race and Other Woeful Tales, 90 Q.J. ECON. 599, 608-10 (1976) (despite its apparent inefficiency, a caste system may remain in equilibrium through the use of powerful sanctions against those who threaten the social system).

6. Becker in fact recognizes this point, describing those with a "taste" for discrimination as including fellow workers and customers as well as employers. G. BECKER, supra note 4, at 14-15; see also Arrow, Models of Job Discrimination, in RaCial Discrimination In ECONOMIC Life 83, 88 (A. Pascal ed. 1972) (fellow workers and customers may also discriminate). 
ultimately prescriptions that are ill-suited to the problem of discrimination in the Umited States in the late twentieth century.

\section{A. Third Parties}

The clearest illustration of discrimination not driven by economic irrationality occurs when third parties are in a position to impose financial punishments on nondiscriminatory einployers. ${ }^{7}$ Suppose, for example, that purchasers or fellow einployees refuse to buy froin or to work for a company that does not discriminate. Even if employers would themselves choose not to discriminate or have no particular view about whether or not to discriminate, third parties can pressure employers to discriminate.

The phenomenon is hardly unusual. Consider, for example, the case of a shopkeeper whose custoiners do not like deahing with blacks or woinen, a commercial airline whose patrons react unfavorably to female pilots, a law firm whose chents prefer not to have black lawyers, or a hospital whose patients are uncomfortable with female doctors or black nurses. The persistence, for a long period, of private segregation in major league baseball is a familiar example of this basic phenomenon. ${ }^{8}$

In all these cases, an einployer who introduces norms of equality into the work force will be pumshed, not rewarded. For the employer faced with consumers or employees who prefer discrimination, a decision to engage in discrimination is in an important respect neutral. He is simply maximizmg his profits by respecting consumer demand. Indeed, an employer who refuses to discriminate will be engaging in what is, from his point of view, a form of affirmative action. If he must become a nondiscriminator, it will be to proinote the long-range goal of race and sex equality. ${ }^{9}$

All this suggests that discrimination can be a product not of prejudice, but of responses to inarket pressures from third parties. Of course, prejudice is in some sense at work - by customers or fellow employeesbut the discriminator is not himself acting froin prejudice or irrationality.

7. Here I largely follow Akerlof, supra note 5, at 608-10 (threat of sanctions by third parties may keep apparently inefficient caste system in equilibrium); see also id. at 610 ("those who fail to follow ... the caste customs do not gain the profits of the successful arbitrageur but instead suffer the stigma of the outcast").

8. Customer discrimination also has become apparent quite recently in the market for baseball cards, which shows a $10 \%$ to $13 \%$ "racial discount" for the cards of black players. See Nardinelli \& Simon, Customer Racial Discrimination in the Market for Memorabilia: The Case of Baseball, 105 Q.J. ECON. 575, 594 (1990).

9. The idea that discrimination is a result of hostility or prejudice lies at the root of attacks on affirmative action. In fact, discrimination is sometimes based on rational self-interest. If this is so, the distinction between affirmative action and an antidiscrimination principle becomes much thinner. See infra text accompanying notes 16-18. 
It is here that the traditional understanding is misconceived. ${ }^{10}$

\section{B. Statistical or Economically Rational Discrimination}

Sometimes discriminatory behavior is a result of generalizations or stereotypes that, although over-broad and perhaps imvidious, provide an economically rational basis for einployment decisions. ${ }^{11}$ Stereotypes and generalizations are, of course, a common ingredient in day-to-day decisions. There are informational costs im making distinctions within categories, and sometimes people prefer to avoid the often far inore costly exammation of the merits of the particular employee.

Such categorical judgments are not only pervasive, but they are also entirely legitimate in most settings. We all depend on them. Employers rely on "proxies" of many sorts, even though those proxies are overbroad generahizations and far from entirely accurate. Test scores, previous employment, college or high school education, prestige of college attended - all these are part of rational employment decisions. Emphasis on these factors is a common form of stereotyping, and at least in ordinary circumstances, it would be odd to say that such factors reflect hostility or prejudice of the invidious kind.

At least in some contexts, race and sex operate as similar proxies. In various ways, blacks differ from whites and women from men. There are real differences between the two groups. Indeed, in hight of past and present discrimination against blacks and woinen, it would be shocking if there were no group-based differences. Women, for example, are more hikely than men to be the primary caretakers of children and more likely to leave the employment market because of that role. ${ }^{12}$ Along every indicator of social welfare-poverty, education, einployment, vulnerability to private (or public) violence, participation in violent crime-blacks are proportionally less well off than whites. In light of those differences, it is fully possible that in certain settings, race- and sex-based generalizations

10. In one respect, courts have acknowledged this point. In title VII litigation, customer preferences do not count as a "bona fide occupational qualification" (BFOQ) sufficient to justify facially discriminatory hiring practices. See, e.g., Diaz v. Pan Am. World Airways, 442 F.2d 385, 389 (Sth Cir.) (holding that customer preference for male flight attendants was not a BFOQ), cert. denied, 404 U.S. 950 (1971); Fernandez v. Wynn Oil Co., 653 F.2d 1273, 1276-77 (9th Cir. 1981) (customer preference not BFOQ); see also 29 C.F.R. $\S 1604.2(a)(1)(i i i)(1990)$ (preferences of coworkers or customers not BFOQ).

11. Arrow, supra note 6, at 96-97 (stating that costs of acquiring more accurate information may make discrimination economically "rational"); Strauss, The Myth of Colorblindness, 1986 SuP. CT. REV. 99, 108-10 (defining and illustrating concept of "rational" discrimination); see also Phelps, The Statistical Theory of Racism and Sexism, 62 AM. EcoN. REv. 659, 660 (1972) (presenting a model for "economically rational" discrimination).

12. This phenomenon of course does not mean that differential treatment is permissible. Whether such treatment should be allowed need hardly depend solely on its being economically rational. See infra text accompanying notes 63-64. 
are economically rational as proxies for relevant characteristics. Moreover, race or sex in soine contexts may be every bit as accurate a predictor of job performance as, say, test scores, education, and previous employment. And in some cases, rehance on inore direct and individualized devices might be too costly to be worthwhile.

If race or sex can be a good predictor of performance, an employer inay discriminate not because he hates or devalues blacks or women, or because he has a general desire to avoid them, or is prejudiced in any of the senses I have discussed, but because he believes (on the basis either of plausible assumption or actual experience) that the relevant stereotypes have sufficient truth to provide a rational basis for einployment decisions. An employer might, for exainple, beheve that women are more likely to leave a high-pressure job than inen, or that blacks are less likely to have the necessary training. For the handicapped, the same scenario is of course readily predictable; real differences call for differential treatinent. Ordinary prejudice and irrationahty are thus not at work.

It is important to be careful with this point. As I understand it, statistical discrimination occurs when the einployer does not harbor irrational hatred or discriminatory feelings, but instead acts according to stereotypes of the sort market actors typically rely on, which are of course false in soine or inany cases, but which cannot readily be abandoned for more direct imquiries. I do not inean to deny that ordinary, irrational prejudice accounts for a significant amount of discrimination. Nor do I deny that it is hard both in practice and $\mathrm{m}$ principle to distinguish between ordinary prejudice and econornically rational stereotyping.

Soinetimes, of course, employers who refuse to follow a stereotype inay find job candidates who will inove thein far ahead in the marketplace. Moreover, the decision about what kinds of economically rational stereotypes to adopt might itself reflect prejudice. ${ }^{13}$ People are highly selective in creatimg and using the very categories through which they view people-as college graduates? as children of successful parents? as nonreligious? as white males? as tall? as good-looking? by what criteria?

People are also selective in deciding which categories ought to count in various sectors. Thus, for example, the use of sex as a proxy for flexibility with respect to overtime work may be fully rational; but as I have noted, selectivity in the choice of the proxy is a product of prejudice if, as is usual, other equal or better proxies are available. Indeed, like the selection of stereotypes, the selection of criteria inight itself be a product

13. Cf. G. Lakoff, Women, Fire, and Dangerous Things: What Categories Reveal ABOUT THE M1ND 12-57 (1987) (discussing processes of categorization); M. MINOW, MAK1NG ALL THE DIFFERENCE 19-48 (1990) (discussing use of categories as lens through which difference is viewed). 
of a kind of prejudice. ${ }^{14}$ Finally, people tend to notice events that are consistent with previously held stereotypes and to disregard events that are inconsistent with them. ${ }^{15}$ Here there is a built-in obstacle to changes in social norms even when those norms decreasingly mirror reality.

One might agree with all this and still acknowledge what seens undoubtedly true, that discrimination sometimes persists because it is economically rational to rely on a race- or sex-based generalization. And because contemporary law singles out one kind of rational stereotyping to ban it, the distinction between affirmative action and antidiscrimination norms becomes extremely thin and perhaps invisible in principle. ${ }^{16}$ The antidiscrimination principle-of course, widely accepted-forbids government from discriminating against blacks and women, even when such discrimination is econormically rational. Affirmative action-of course, a highly controversial practice-calls for employment and other preferences for members of disadvantaged groups. The two ideas are often thought to be in severe tension, ${ }^{17}$ and indeed, for advocates of affirmative action, the antidiscrimination principle soinetimes seems an einbarrassinent.

In some settings, however, an antidiscrinination norm, conceived as a barrier to economically rational behavior, has the same purposes and effects as affirmative action. Affirmative action is controversial partly because it can be economically irrational, can impose serious social costs, and harms innocent victims. ${ }^{18}$ But an antidiscrimination principle often does precisely the same as what affirmative action does, and also does it in the interest of long-term social goals. For example, an antidiscrimination norm may require innocent victims to sacrifice-customers may be required to pay higher prices-in order to produce long-term equality.

A great failure of the assault on affirmative action is its inability to account for the ways in which a requirement of nondiscrimination involves very much the same considerations. Indeed, the distinction between affirmative action and antidiscrimination is sharp only to those who see discrimination as always grounded in hostility and irrationality, which it clearly is not.

14. See Strauss, supra note 3, at $957-58$ (suggesting a "reversing the groups" test to determine whether the choice of classification criteria reflects discriminatory intent).

15. See E. Aronson, The Social Animal 174-76 (1972). "Prejudice[d] people see the world in ways that are consistent with their prejudice." Id. at 174.

16. See Strauss, supra note 11, at 130 ("There are fundamental similarities betwecn nondiscrimination and affirmative action.").

17. See Van Alstyne, Rites of Passage: Race, the Supreme Court, and the Constitution, 46 U. CHI. L. REV. 775, 802-03 (1979) (equating affirmative action with discrimination); id. at 809 (referring to affirmative action as a "suggestion to relicense racial discrimination").

18. See, e.g., $i d$. at 801-02 (affirmative action program in Regents of the University of California v. Bakke, 438 U.S. 265 (1978), harmed innocent victims); id. at 805-08 (no rational way to determine racial eligibility for affirmative action program); see also Strauss, supra note 11, at 110-11. 


\section{The Effects of Discrimination on Human Capital and Problems of Preference Formation}

Suppose that there has been widespread discrimination for any number of reasons: employers have a taste for discrimination; third parties impose pressure on employers to discriminate; employers use statistical generalizations that are rational. Once the discrimination becomes established, members of disadvantaged groups will suffer from harmful effects on investment in human capital and on preference formation. ${ }^{19}$

\section{Human Capital}

The productivity of participants in the labor market is endogenous to, or partly a product of, discrimination in that market. It is a mistake to take productivity within any social group as static or unaffected by employer decisions. Such decisions will have important dynamic effects on how blacks and whites, or woinen and inen, choose to invest in human capital. Decisions about education, child care, training, drug use, employment prograins, and tradeoffs between work and leisure will be affected by existing patterns of discrimination. In a market having such discrimmation, inembers of disadvantaged groups will invest relatively less in education and training programs. Indeed, lower investments on their part are perfectly rational. As inarket actors, women should invest less than inen in traiming to be (for exainple) pilots, econoinists, politicians, lawyers, or law professors if these professions discriminate against women and thus reward their investment less than that of men.

The result will often be a vicious circle or even a spiral. Because of existing discrimination, the relevant groups will imvest less in human capital; because of this lower investment, the discrimination will persist or perhaps mcrease as its statistical rationality itself increases; because of this effect, investments will decrease still further, and so on.

Undoubtedly, this picture is too bleak in inany situations. Other proxies, not rooted in sex and race, have frequently evolved and employers have used thein. Such proxies are ordmarily far inore accurate, and employers who use thein soinetimes prosper. More generally, the extraordinary persistence of blacks and women in attempting to enter professions dommated by white inen is one of the inost striking phenoinena of the post-World War II period. Blacks and women frequently appear to invest huge amounts in human capital, even in sectors that treat them inhospitably. ${ }^{20}$ But there is little question that discrimination does have a large effect on investments in human capital in many con-

19. Arrow, supra note 6, at 88; Lundberg \& Startz, Private Discrimination and Social Intervention in Competitive Labor Markets, 73 AM. ECON. REv. 340, 342 (1983).

20. In fact, some people in some circumstances respond to discrimination by increasing rather than decreasing their investments in human capital. In Western history, some racial and ethnic 
texts, and that the hostile reception given to disadvantaged groups perpetuates their exclusion from certain sectors of the economy. In that case, inequality will be the result of discrimination that is itself the product not only of past irrational hostility or prejudice, but also of a far more complex system of imteractions with economically rational employment decisions.

\section{Preferences}

An additional problem is that private preferences, of both discriminators and their victims, tend to adapt to the status quo, and to do so in such a way as to make significant change hard to achieve. The reduction of cognitive dissonance is a powerful motivating force: people attempt to bring their behiefs and perceptions in line with existing practice. ${ }^{21}$ The victims of inequahity tend to reduce dissonance by adapting their preferences to the available opportunities. Consider the story of the fox who concludes that he does not want unavailable grapes because he considers them sour: he considers them sour because they are unavailable. ${ }^{22}$ Or people may adapt their aspirations to the persistent and often irrationally held belief that the world is in fact just. ${ }^{23}$ The beneficiaries of the status quo tend to do the same, concluding that the victims deserve their fate, that they are responsible for it, or that the current situation is part of an intractable, given, or natural order. ${ }^{24}$

There is extremely powerful evidence in the psychological literature to support these claims. ${ }^{25}$ For example, people who behave cruelly change their attitudes toward the objects of their cruelty and thus devalue them. Observers of cruelty and violence tend to do the same. The phenomenon of blaming the victim has clear cognitive and

groups have prospered as a result of such investments, notwithstanding discriminatory tastes on the part of employers, customers, and fellow employees.

21. See L. Festinger, A Theory of Cognitive Dissonance 18-19 (1957). On the phenomenon in this particular context, see Arrow, supra note 6, at 97. See generally J. ELSTER, SOUR GRAPES 15-26 (1983).

22. See AEsop's FABLes 21 (Hague ed. 1985); see also J. ElsTeR, supra note 21, at 110-40 (describing "sour grapes" response as a way to reduce cognitive dissonance).

23. See J. ElSTER, supra note 21, at 101-08 (asserting that the search for explanations for injustice stems from theology and biology); M. LERNER, THE BELIEF IN A JUST WORLD: A FUNDAMENTAL DEIUSION 123-26 (1980) (because of the belief that the world is just, victims may blame themselves in order to assert control over their otherwise meaningless misfortune).

24. See generally M. LERNER, supra note 23, at 50 (results of experiment show that people tend to condemn an apparently blameless victin to reassert their belief in a just world and to lessen cognitive dissonance).

25. See, e.g., sources cited supra notes 21 \& 23; E. ARONSON, supra note 15, at 89-137 (discussing numerous experiments of people trying to reduce cognitive dissonance); Furnham \& Gunter, Just World Beliefs and Attitudes Towards the Poor, 23 BRIT. J. Soc. PsYchology 265, 268 (1984) (noting that observers tend to view the poor as responsible for their fate); Janoff-Bulman, Timko \& Carli, Cognitive Biases in Blaming the Victim, 21 J. EXPERIMENTAL Soc. Psychology 161 (1985) (discussing sources of the phenomenon of "blaming the victim"). 
motivational foundations. The notion that the world is just, and that existing inequalities are deserved or desired, plays a large role in forming preferences and beliefs. All these phenomena have played an enormous part in the history of racial and sexual discrimination.

The inevitable effect of a discriminatory status quo on preferences and beliefs is closely related to the plienoinenon of decreased investinent in liuman capital. In both cases, the response to discrimination is endogenous ratler than exogenous and has the consequence of perpetuating existing inequalities. But witl respect to preferences and beliefs, the effect is especially pernicious. And when there are harmful effects on the development of preferences and beliefs, discrimination will occur for reasons that are not directly traceable to acts of irrationality or prejudice. ${ }^{26}$

\section{In General: Reinforcing Effects}

The arguments I have offered thus far build on standard econoinic accounts of discrimination. It is notable that none of the various effects reflects an uncontroversial market failure in the conventional sense. ${ }^{27}$ The incorporation of racist or sexist preferences is efficient, if the efficiency criterion is based on private wilhingness to pay; ${ }^{28}$ the same applies with profit-1naximizing reactions to the desires of third parties and with statistical discrimination. In all these cases, governinental interference will probably produce an efficiency loss, at least in the short term. ${ }^{29}$

The inost likely exception is the effect of discrimination on liuman capital and preference formation. ${ }^{30}$ In that case, it is possible that discrimination will produce a serious externality in the form of liarniful effects on prospective labor market entrants, with a corresponding efficiency loss. If discrimination discourages meinbers of disadvantaged groups froin investing in human capital, it will produce large social losses by decreasing potentially large sources of productivity. Ideas of this sort inay provide the basis for a fully plausible efficiency justification for antidiscrimination law.

26. Of course prejudice and irrationality are in the background here, in that they helped create the conditions under which the relevant acts take place. In this sense, prejudice and irrationality are hardly irrelevant. But to say that existing distributions of benefits and burdens between blacks and whites is in significant part a legacy of prejudice is quite different from saying that particular acts of present discrimination are produced by prejudice or irrationality on the part of the discriminator. See supra text accompanying note 10.

27. My use of the term "market failure" here builds on the conventional economic analysis.

28. But cf. Donohue, Is Title VII Efficient?, 134 U. PA. L. REv. 1411, 1430 (1986) (concluding that title VII increases "total social welfare," apparently relying on a conception of efficiency based on a notion of social output or production). The same criterion can be found in Schwab, Is Statistical Discrimination Efficient?, 76 AM. ECON. REV. 228, 233 (1986) (noting that statistical discrimination may be "socially inefficient").

29. But see Donohue, supra note 28, at 1420-21, 1430; Schwab, supra note 28, at 233.

30. See Lundberg \& Startz, supra note 19 , at 342. 
There is, however, an optimal level of investınent in huinan capital, and it is not entirely clear why and to what extent investments that are adaptive to einployer behavior in the labor inarket should be seen as suboptimal. Any generalization rehed on in the labor market will have a signaling effect that will shift investments in human capital. It is not easy to develop a model to explain which of those signals produce suboptimal investınents. Often, then, markets will perpetuate discrimination for reasons that are unrelated to the market failures that provide traditional economic grounds for legal intervention.

More importantly, each of these effects reinforces the others in potentially powerful ways. If there is ordinary prejudice, it will interact with statistical discrimination to produce more of both. People tend to notice events consistent with their prejudice and to disregard events that are inconsistent with them, thus resulting in more prejudice and more statistical discrimination. If third parties attempt to promote discrimination, they will increase both prejudice and statistical discrimination. Employers will hire fewer ineinbers of disadvantaged groups, who will in turn appear less frequently in desirable positions, with consequent reinforcing effects on both prejudice and statistical discrimination.

In addition, if there is prejudice and statistical discrimination, and if third parties promote discrimination, there will be decreased investments in human capital and increasing adaptation of preferences and beliefs to the status quo. These will be perfectly reasonable responses. And if there are decreased investments in human capital, the result will be increases in prejudice, statistical discrimination, and third-party effects. Statistical discrimination will becoine all the inore rational; prejudice will continue; and consuiners and employers will be inore likely to discriminate.

Of course, it would be necessary to compile detailed factual evidence to assess the magnitude of these effects. Analysis of that issue is difficult in the abstract. But the general point should be clear. Discrimination is not a simple result of prejudice or hostility, but instead reflects a far more complex interplay of past and present discrimination, social and economic factors, and economically rational decisions. If civil rights law treats decisions to discriminate as based on prejudice or irrationahty, it will badly misconceive the problem and produce remedies that are illsuited to its elimination.

II

Fallacy \#2: Principles of Compensatory Justice Should Play a Guiding Role in Civil Rights Policy

Much of the rhetoric of the civil rights novements is built on principles of compensatory justice. According to these principles, those who 
have caused harm to a person or group must repair the harm. For example, slavery and segregation have played a large role in producing secondclass citizenship for blacks in America. A principal purpose of civil rights law is to undo the historical wrong, thus returming to the status quo ante.

Those who base civil rights law on principles of compensatory justice attempt to link pubhic and private law, assimilating the problem of discrimination to the problems that arise in ordinary tort actions. And there is certainly something valuable to the effort. If a person is in a subordinate position because of wrongs done to her, or even to her parents, that person's inequality is a product of a morally irrelevant factor ${ }^{31}$ in the form of an injustice, and for that reason she has a legitimate claim to redress. In this way, the compensatory rhetoric of the civil rights movement properly links contemporary efforts to past injustices.

In important respects, however, the model of compensatory justice madequately captures the nature of the problem and is therefore a recipe for confusion. The confusion arises im the many cases in which courts approach questions of equality by way of traditional principles of compensatory justice. For example, the requirement of "discriminatory intent"32 might well be understood as an effort to adhere to compensatory principles in this setting. The question, thus conceived, is whether an identifiable actor has harmed an identifiable person in an identifiable way. To abandon the touchstone of intent would lead courts far from the compensatory inodel. It would lead courts to require redress of social wrongs committed by third parties in the distant past, which would involve conspicuous social reordering and harms to innocent persons, rather than a restoration of some well-defined status quo ante. ${ }^{33}$

To be sure, the approach of the courts-and especially of the Supreme Court-has been based on a narrow conception of compensation. A broader compensatory principle would promote far more legal victories for members of disadvantaged groups. ${ }^{34}$ In this more expansive view, the redress of harms other than those created by the particular practice in question would be the goal of the equality principle. The notion of compensation would remain, but it would require public and private employers to ensure that the distribution of benefits and burdens

31. See J. RAwls, A ThEORY OF JuSTICE 100-04 (1971); see also infra text accompanying note 61 .

32. E.g., Village of Arlington Heights v. Metropolitan Hous. Dev. Corp., 429 U.S. 252, 265 (1977); Washington v. Davis, 426 U.S. 229, 239 (1976).

33. The point is suggested by the Court in Davis, 426 U.S. at 248.

34. The Court's discriminatory intent test has been subject to criticism. See, e.g., Lawrence, The Id, the Ego, and Equal Protection: Reckoning With Unconscious Racism, 39 STAN. L. REv. 317 (1987); Strauss, supra note 3, at 954-56. 
between blacks and whites would be roughly what it would have been without the legacy of discrimination.

It is doubtful, however, that such an approach would be feasible. What would the world look like if it had been unaffected by past discrimination on the basis of race and sex? The general problem is that the compensatory model, in any form, is based on notions of causation, injury, and restoration to the status quo ante that are well adapted to tort or contract setting, but singularly ill-suited to the problem of discrimination in the United States.

We might begin with the issue of school desegregation, where compensatory ideas play a proininent role. Suppose that a school district engaged in de jure segregation until 1954, and that in 1958, 1968, or 1978 , a judge issues a finding to that effect. What remedy ought to be imposed? The Supreine Court's cases are exceptionally complex on this point. $^{35}$ The Court's basic approach seems to be an attempt to restore the status quo ante. In desegregation cases, the Court asks whether the proposed reinedy will restore the system to what it would have been were it not for past acts of segregation. Under this rationale, the Court has invalidated "freedom of choice" desegregation plans, emphasizing that they will bring about less desegregation than would have occurred if there had been no segregation in the first instance. ${ }^{36}$

Primciples of compensatory justice play a prominent, indeed central role here. They define the very nature of the inquiry. Some Justices, for example, emphasize the difficulty of finding a good causal comiection between post-1970 or 1980 practices and pre-1954 discrimination. ${ }^{37}$ For them, the weak causal connection means that the law should not make people restructure present practices. By contrast, other Justices emphasize the legacy of past discrimination and what they see as its undeniable causal connection to present patterns of segregation. ${ }^{38}$

Both sides appear, however, to miss the fact that issues of causation, and the compensatory principles that underlie them, have little coherence in this context. An inquiry into the amount of racial integration that would have occurred in a world unaffected by racial segregation is likely to be empirically unanchored, indeed, chimerical. Social scientists, let alone judges, are simply not equipped to answer that question-not because they lack appropriate tools, but because the question itself is of

35. See, e.g., Dayton Bd. of Educ. v. Brinkman (Dayton II), 443 U.S. 526, 537-39 (1979) (intentional establishment of dual school system before 1954 creates continuing obligation to undertake affirmative acts to desegregate school district); Columbus Bd. of Educ. v. Penick, 443 U.S. 449,458 (1979) (same). These issues, of course, lie behind Board of Education of Oklahoma City Public Schools v. Dowell, 111 S. Ct. 630 (1991).

36. E.g., Green v. County School Bd., 391 U.S. 430, 440 (1968).

37. See, e.g., Dayton Bd. of Educ. v. Brinkman (Dayton I), 433 U.S. 406, 417, 420 (1977).

38. See, e.g., id. at 423 (Brennan, J., concurring). 
uncertain epistemological status. One simply cannot sort out the connection between legal segregation in 1950 and educational patterns in 1990. The status quo ante-whatever it nright have been-cannot be conceptualized. To try to resolve issues bearing on desegregation remedies in terms of compensatory primciples is to ask unanswerable questions.

The problem is far more general. What would our practices be in a world without race and sex discrimination? How would one treat (for example) veterans' preferences in the absence of sexism, or literacy tests for voting and employment in the absence of racism? In all these cases, the restoration of a status quo ante is a conceptually incoherent task. Moreover, it is not even clear whether past discrimination presents the basic reason for the legal responses to the present status of blacks. Whether such discrimination is a necessary or sufficient condition for "remedial" efforts is by no ineans self-evident. ${ }^{39}$

Similar problems arise in cases involving affirmative action. The Supreme Court has frequently indicated that race-conscious measures are permissible only as a "remedy" for identifiable acts of purposeful discrimimation undertaken within the jurisdiction of the governmental institution engaging in affirmative action. ${ }^{40}$ Here, too, compensatory primciples are in the forefront, allowing affirmative action only as a response to tort-like acts. By contrast, affirmative action grounded in an effort to overcome "societal discrimination" is generally impermissible. ${ }^{41}$ In so holding, the Court has emphasized that the victims of affirmative action are either employers or, much more frequently, white people or men who never engaged in discriminatory conduct.

The problem of innocent victinns ${ }^{42}$ appears to be a principal impetus behind the requirement of a showing of past discrimination. Under current law, affirmative action can thus be defended most easily in tort-like terms as an effort to restore a status quo ante that has been unsettled by identifiable acts producing identifiable harms to identifiable actors. The problem here, as elsewhere, is that affirmative action does not fit the tort model. Although the redress of past discrimination is an important element in the theory and practice of civil rights law, there is no welldefined status quo agaimst which compensatory principles can operate.

To put the point most generally: It is true that past acts of discrimination help account for the socially subordinate status of disadvantaged groups, and when this is so, some sort of remedial principle should play a

39. See Sullivan, Sins of Discrimination, 100 HARv. L. REv. 78, 83-84, 96 (1986) (suggesting that the Court could have justified "remedial" affirmative action plans by reference to exclusively forward-looking goals, such as improving education or promoting diversity in the workplace).

40. See, e.g., City of Richmond v. J.A. Croson Co., 488 U.S. 469, 509 (1989).

41. See, e.g., id. at 499.

42. By this term, I mean whites or men who may benefit from but are not responsible for past and present discriminatory practices. 
role in civil rights theory. But to try to decide questions about the scope and nature of antidiscrimination policy by reference to compensatory notions is a recipe for confusion and for unproductive-because unresolvable-disagreements.

\section{III}

FAllacy \#3: COURTS ARE THE ApPropriate INSTITUTION fOR Bringing About Social Change IN the AREa of Civil Rights

During and after the period of the Warren Court, it has been commonplace to suggest that federal courts should set inuch of civil rights policy through the process of constitutional adjudication. ${ }^{43}$ The courts' insulation-from an electoral process that is often said to have produced civil rights violations in the first place-is considered a coinparative virtue, allowing the judges to implement antidiscrimination principles without being affected by political biases. There can be no question that because of their insulation, judges have often been in an unusually good position to elaborate and implement principles of antidiscrimination. But for several reasons, reliance on the judiciary inay have been a mistake. It may have diverted attention from more productive alternatives and at the same time disserved the very causes at issue. In any case, such reliance seems a poor strategy for the future. Three considerations are relevant here.

\section{A. Efficacy}

Judicial decisions are of limited efficacy in bringing about social change. Study after study has confirmed this basic conclusion. ${ }^{44}$ Brown v. Board of Education ${ }^{45}$ is usually offered as a counter-example, but it is $\mathrm{m}$ fact the most conspicuous confirmation of the point. ${ }^{46}$ Ten years after the decision, no inore than about two percent of black children in the South attended desegregated schools. ${ }^{47}$ It was not until 1964, after Congress and the executive branch became involved, that widespread desegregation actually occurred. The Court is far more effective at vetoing a decision of another government entity than it is at effecting social change on its own. Of course, it is possible that the legislative and executive actions would not have occurred without the spur of Brown, but

43. See, e.g., Fiss, Foreword: The Forms of Justice, 93 HARV. L. REv. 1 (1979).

44. See D. Horowitz, The CourTs and Social Policy 56-62 (1977); R. Melnick, Regulation and the Court: The Case of the Clean Air Act 110-12 (1983); G. Rosenberg, The Hollow Hope: Can Courts Bring About Social. Change? (forthcoming Oct. 1991).

45. 347 U.S. 483 (1954).

46. See G. Rosengerg, supra note 44 , at $42-71$.

47. See G. Stone, L. Seidman, C. Sunstein \& M. Tushnet, Constitutional Law 474 (1986). 
even this seems uncertaim. ${ }^{48}$

The decision in Roe v. Wade ${ }^{49}$ may be another illustration, though the picture here is more complex. It is undoubtedly true that the decision increased women's access to safe abortions, and to some extent it may have increased the legitimacy of abortion. By 1973, however, state legislatures were moving firmly to expand legal access to abortion, ${ }^{50}$ and it is likely that a broad guarantee of access would have been available even without Roe. However surprising the point may be, Roe did not dramatically increase the actual number or rate of abortions. ${ }^{51}$ Perhaps more fundamentally, the decision may well have created the Moral Majority, helped defeat the equal rights amendment, and undermined the women's inovement by spurring opposition and demobilizing potential adherents. $^{52}$ At the same time, Roe may have taken national policy too abruptly to a point toward which it was groping more slowly, ${ }^{53}$ and in the process may have prevented state legislatures from working out longlasting solutions based upon broad public consensus.

We might in this regard contrast Roe $v$. Wade with the Civil Rights Act of 1964, a legislative enactment brought about through general public support. The foundational civil rights law in the United States has a kind of legitimacy and support that makes it extremely hard to amend at

48. See G. ROSENBERG, supra note 44 , at 107-56.

49. 410 U.S. 113 (1973).

50. See Morgan, Roe v. Wade and the Lesson of the Pre-Roe Case Law, 77 Mich. L. REv. 1724, 1726 (1979).

51. There is good reason to believe that in the early $1960 \mathrm{~s}$, there were between 1.0 and 1.5 million abortions in the United States each year. That is, at least $20 \%$ and perhaps as many as $30 \%$ of all pregnancies ended in abortion. See, e.g., L. LADER, ABORTION 2 (1966) (referring to the "recent" estimate of 1.5 million); R. ScHWARTZ, SEPTIC ABORTION 7 (1968) (in the late 1960s, over $20 \%$ of pregnancies terminated in illegal abortions, resulting in approximately 1.2 million unlawful abortions per year); J. VAN DER TAK, ABORTION, FERTILITY, AND CHANGING LEGISLATION: AN INTERNATIONAL REVIEW 72-73 (1974) (referring to "the wide acceptance of a round figure of 1 million induced abortions per year (of which only an estinuated 8,000 were legal), corresponding to ... an abortion ratio of almost 30 per 100 hve births"); Whittenore, The Availability of Non-Hospital Abortions, in 1 ABORTION IN A CHANGING WORLD 217 (R. Hall ed. 1970) ("the oft-quoted figure of one million criminal abortions in the United States is a fairly reasonable estimate"); see also $\mathrm{H}$. RODMAN, B. SARvis, \& J. BONAR, THE ABORTION QUestion 23 (1987) (estinate of 1 million illegal abortions per year prior to Roe); Fox, Abortion Related Deaths, in 98 AM. J. OESTETRICS \& GYNECOLOGY 645, 645-46 (1967) (estiniating that between 35,000 and 100,000 woinen annually had unlawful abortions in California alone during this period). Police reports reveal that in 1960, illegal abortion was the third largest illegal enterprise in the United States, after gambling and narcotics. See E. Schur, Crimes Without Victims, Deviant Behavior and Public Policy 25 (1965). But see N. LEE, THE SEARCH FOR AN ABORTIONIST 5-15 (1969) (describing the difficulty of finding aceurate data on the numbers of illegal abortions because they are earried out in a decentralized way).

52. See J. MANSBRIDGE, WHY WE LOST THE ERA 122-28 (1986) (documenting some of these propositions).

53. See Morgan, supra note 50, at $\mathbf{1 7 2 6 .}$ 
all except to broaden it. At least in part because of its judicial source, Roe has no such status.

We have seen some evidence for all these propositions in the recent past, with the extraordinary public reaction to the Supreme Court's Webster decision. ${ }^{54}$ The Court's partial retreat from Roe may well have galvanized the women's inovement in a way that will have more favorable and fundamental long-term consequences for sexual equality than anything that could have coine froin the Court. This is not to say that $R o e$ was necessarily wrong, either as a matter of constitutional interpretation or as a matter of primciple. But its effectiveness has been limited, largely because of its judicial source. The civil rights movement has been similarly spurred by recent Supreme Court decisions, which have led in turn to an aggressive civil rights bill supported in large measure by a Republican President. ${ }^{55}$

More generally, it is not clear that the United States has developed significantly different antidiscrimination primciples from those in other liberal democracies that lack judicial review (nost notably France, England, and until recently, Canada) or that have such review but have quite different constitutions (nost notably, Germany). Of course, judicial review has in some settings accomplished considerable good and even introduced important changes into American society. But the evidence suggests that judges are less effective than the elected branches of the government in attempting to reform systems of discrimination.

\section{B. Democracy, Citizenship, Compromise, and Legitimacy}

For achieving sensible and effective reform, pohtical channels are often far better than the courts. The resort to politics can produce a kind of citizen mobilization that is a public and private good, and can inculcate political commitments, broader understanding, feelings of citizenship, and dedication to the community. All these nay in turn spur deeper and wiser social change nit the area of civil rights than rehance on the judiciary would provide. Martin Luther King, Jr., may well have been a more important catalyst for constitutional change than any or

54. Webster v. Reproductive Health Servs., 492 U.S. 490 (1989).

55. The Civil Rights Act of 1990 was introduced in the U.S. Senate and House of Representatives in February 1990. S. 2104, 101st Cong., 2d Sess., 136 CoNG. REC. S1018-21 (daily ed. Feb. 7, 1990); H.R. 4000, 101st Cong., 2d Sess., 136 CoNG. REC. H364 (daily ed. Feb. 7, 1990). President Bush did veto the Civil Rights Restoration Act, but his disagreement actually focused only on one part of the Act, not exactly a trivial provision, but one that should be seen as a inere piece in an extreinely broad and far-ranging measure. President Bush approved of alinost all other aspects of that measure. See President's Veto of S. 2104-Civil Rights Act of 1990, 1990 U.S. CODE CONG. \& ADMIN. NEwS D36. The fight over the Act is not yet over; Congress reintroduced the Act in January 1991. H.R. 1, 102d Cong., 1st Sess., 137 CONG. REc. H53 (daily ed. Jan. 3, 1991). 
even all of the Warren Court's race decisions. ${ }^{56}$

It is often thought that the very fact that courts are unrepresentative is one of their strengths; they serve as an available alternative to democratic channels. But reliance on the courts has large and hidden disadvantages. It may divert energy and resources from political processes, and the substitution effect imposes large costs on these processes. And if questions of morality tend to become questions of constitutional law, their resolution before nine judges can harm the practice of citizenship. As noted, some of this effect is already visible in the abortion controversy. The same may also be true for racial discrimination, though the evidence is more ambiguous here.

This is not to deny that judicial review can make up for systemic mequalities im majoritarian processes and impose the kind of principled dehiberation that comes to such processes only with difficulty. But reliance on an aggressive Court is, from the standpoint of civil rights policy, the furthest thing from an unambiguous good; and this is so even if the Court's goals are sound.

\section{The Narrowing Focus of Adjudication}

Despite ninovative theories and practices, ${ }^{57}$ adjudication remains an extremely poor system for achieving social reform. Courts are rarely expert in the area before them. Moreover, the focus on the litigated case hainpers judges' efforts to understand the complex systemic effects of legal intervention. A decision to require expenditures on school busing might, for example, divert resources froin an area with an equal or greater claimi to the public fisc.

More fundamentally, legal thinking and legal procedures are most suited to ideas growing out of the tradition of compensatory justice, which is poorly adapted to the achievennent of serious social reform. Adjudication is ill-suited to undertaking the necessary changes. Many of the most important problems in current civil rights policy are systemic and complex. The lack of adequate schools, job training, or jobs creates a cycle of poverty, vuhierability to drugs and to crime, teenage pregnancy, and single-parent households. ${ }^{58}$ Courts simply lack the tools to respond to these probleins. Of course, they might make things better

56. The common view that the Court's decisions helped to mobilize political actors and protest, or paved the way for King, has surprisingly little empirical support. See G. RosenBerG, supra note 44 , at $112-13$.

57. R. Cover, O. Fiss \& J. Resnik, Procedure (1988), can be understood as an attempt to revise the subject of civil procedure through a conception that takes social reform as a central project of the judiciary. It collects a wide range of theories and practices directed to that end.

58. See generally W. Wilson, The Truly Disadvantaged 21-46 (1987) (analyzing statistics about violent crimes, family incomes, employment, and out-of-wedlock births that contribute to the problems faced by inner-city racial minorities). 
rather than worse. But the legislative and executive branches must provide the principal initiative for the necessary programs.

These criticisms of the judiciary are hardly novel. Though voiced most recently by conservatives during and after the period of the Warren Court, critics voiced analogous complaints during the New Deal period, when it would have seemed extremely peculiar to suggest that courts should shape social reform for the disadvantaged. Indeed, the rise of modern regulatory agencies was largely a product of a belief that the judiciary lacked the will, the means, and the democratic pedigree to create social reform on its own. ${ }^{59}$ Witll respect to civil rights, we slould see a similar constellation of ideas in the period we are now entering.

IV

\section{NEW FOUNDATIONS}

Thus far, the discussion has been largely negative. I liave argued that three of the major clainis of the civil rights movement, from the 1950 s to the present, are at best incomplete. Frequently, discrimination is not a reflection of irrationality or devaluation in the ordinary sense. It is instead rational economic behavior in light of the desires of third parties, statistical discrimination, or the effects of past and existing practices on human capital and existing preferences. Moreover, compensatory principles are poorly adapted to the civil rights setting, since they require courts and other public officials to answer inpossible questions. Finally, reliance on the judiciary carries with it a host of probleins. Among other things, the courts are ineffective at achieving large-scale social reform.

The three problems are closely hinked. Judicial institutions are well matched to the achievement of compensatory justice, and legal remedies are especially suitable if discrimination is a product of individual irrationality or prejudice. An understanding that discrimination is economically rational, or not readily captured in compensatory terins, would call for large institutional and substantive changes in existing civil rights law. In particular, it would emphasize the systemic or structural character of race and sex discrimination and the need for institutions to undertake systemic or structural reforin. Our current understandings of the problem are extreinely ill-adapted to this project.

I have not yet proposed alternative understandings of the problem of discrimination, understandings that might lead to different renedies or institutional arrangements. Indeed, one of the largest gaps in present

59. See Sunstein, Constitutionalism After the New Deal, 101 HARv. L. REv. 421, 424-25 (1987) (New Deal reformers sought to avoid the checks and balances that limited the powers of each branch of government); id. at 437 (Progressives saw judiciary as antidemocratie and aligned with interests of powerful); id. at 443 (New Deal reformers preferred agencies over courts in part because agencies could act more swiftly). 
civil rights theory consists of the absence of a full-fledged explanation of just how to characterize a claim of discrimination and why we should eliminate it. In this highly tentative Section, I will say something about these imquiries.

Provisionally, we might define discrimination to include any decision to treat an otherwise similarly qualified black person, woman, or handicapped person less favorably than a white, able-bodied male, whether the reason for the decision hes in malice, taste, selective einpathy or indifference, economic self-interest, or rational stereotyping. This understanding of discrimmation covers not inerely covert unequal treatment but also facially neutral requirements that would not have been adopted if the group membership of the two parties had been reversed. ${ }^{60}$ It does not cover ineasures inerely having discriminatory effects unless those effects are, in the sense I have just indicated, tied up with racial or sexual bias.

It follows that one who claims discrimination does not seek the prevention of certain irrational acts, or of "prejudice," but asks instead for the elimination, in places large and small, of something like a caste system. Indeed, a large mistake of civil rights policy has been to treat the issue as one of discrimination at all, smce the term tends to connote irrational differentiation - an unacceptable practice to be sure, but not an appropriate description of the problem at hand, which is second-class citizenship. The concept of second-class citizenship, or caste, is hard to define, and I will have to be somewhat vague about it. I do not mean to suggest that the caste-like features of current practices are the saine-in nature or extent-as those features of genuine caste societies. I do mean that the similarities are what should make current practices a reason for collective concern.

The motivating idea behind an anti-caste principle is Rawlsian in character: Without very good reason, legal and social structures should not turn differences that are irrelevant froin the moral point of view into social disadvantages. ${ }^{61}$ They certainly should not be permitted to do so if the disadvantage is systemic. A systemic disadvantage is one that operates along standard and predictable lines, in multiple important spheres of life, and that apphies im realms like education, freedom froin private and public violence, wealth, political representation, and political influence, all of which go to basic participation as a citizen in a democratic society. ${ }^{62}$ Of course, past discrimination is a morally irrelevant factor,

60. See Strauss, supra note 3 , at 956-57 (suggesting such a "reversing the groups" test as the standard for discriminatory intent).

61. See J. RAwLS, supra note 31, at 59, 100-04.

62. See C. MACKINNON, FEMINISM UNMODIFIED 30-31 (1987) (discussing systemic disadvantages suffered by women); J. RAwLS, supra note 31, at 102 (discussing need to justify 
but it is one of a large set of such factors that play a role in the distribution of social benefits and burdens.

In the areas of race and sex discrimination, and of disability as well, the problem is precisely this sort of systemic disadvantage. When coinbined with social practices, difference has the effect of systennatically subordinating the relevant group and of doing so in multiple spheres and along multiple indices of social welfare: poverty, education, potitical power, einployinent, susceptibility to violence and crime, and so forth. That is the caste systein to which the legal system should respond. As we have seen, among the many probleins created by such a systein are adverse effects on huinan capital and on preference formation, and general demoralization of group members. ${ }^{63}$

Differences are usually invoked as the justification for disadvantage-for example, as in the claim that blacks, in important respects and as a group, are different froin whites, or women are different from inenand therefore properly receive different treatment. But different treatinent need not follow froin the fact of difference. For purposes of policy and law, the question is not whether there is a difference-often there certainly is-but whether the legal and social treatinent of that difference can be adequately justified. By itself, the fact of difference does not supply an adequate justification.

Differences that imply inequality are the result of legal and social practices, not of nature, and not of the differences theunselves. The problems faced by the handicapped, for exainple, are a function not of handicap alone (a nost ambiguous idea) but instead of the interaction between physical or mental capacities on the one hand and a set of huinan obstacles made by and for the able-bodied on the other. (In the pervasive use of white and male norms, there are analogies in the areas of race and gender.) It is those obstacles, rather than the capacities taken as brute facts, that create a large part of what it ineans to be handicapped (and unequal). For these purposes, it is not decisive whether a present disadvantage can be tightly counected to an intentionally discriminatory act by a public "tortfeasor," which antidiscrimmation efforts would require.

A few disclaimers are necessary here. The anti-caste principle, if taken seriously, would call for significant restructuring of social practices. For reasons suggested above, the principle is better elaborated and

institutions that make natural differences have social consequences). An anti-caste principle is not "egalitarian." Egalitarianism calls for equality in the resources of different citizens; this principle is indeed foreign to American public law. But the desire to eliminate caste systems has played an important role in American constitutionalism from its inception. See L. HARTZ, The Liberal TRADITION IN AMERICA 1-32 (1965).

63. These points are stressed in Strauss, Racial Discrimination in Employment, 79 GEO. L.J. (forthcoming 1991). 
implemented by legislative and executive bodies, with their superior democratic pedigree and factfinding capacities, than by constitutional courts. Moreover, it is important to acknowledge that for good Rawlsian reasons a wide range of differences are morally arbitrary, and in a market economy those differences are quite frequently and for fully legitimate reasons translated into social disadvantages. Consider, in this regard, educational background, intelligence, strength, existing supply and dennand curves for various products and services, height, perhaps even willingness to work hard.

An anti-caste principle that would attempt, through law, to counteract all these factors would be difficult indeed to sustain. In general, the recognition of such factors is inseparable from the operation of a market econoiny, and a inarket economy is an important source of freedom, prosperity, and respect for different conceptions of the good. The use of such factors is at least sometimes in the interest of the less or even least well off, and in that case, an anti-caste principle that would bar their use seems perverse. Moreover, an anti-caste principle that would override all inorally irrelevant factors would impose extraordinary costs on society, both in its implementation and administration and in its infliction of losses on a wide range of people. Those costs are high enough to make such a global principle immensely unappealing.

The principle therefore has greatest weight in discrete contexts, most notably those concerning race, sex, and disability, where gains by the least well off from current practice are hard to imagine, where second-class citizenship is systemic and occurs in multiple spheres and along easily identifiable and sharply defined lines, where the consequence of current practice is to create continuous developmental harms to inembers of well-defined groups, where there will be no global threat to a inarket econoiny, and where the costs of implementation are not terribly high.

If an anti-caste principle is accepted, the most general question is whether members of the disadvantaged group, or people who might find themselves in that category, could be persuaded that there are good reasons for the practice under attack. ${ }^{64}$ To pose that question is to place

64. An idea of this sort is at work in the original position set out in J. RAwLS, supra note 31, at 103; see also City of Cleburne v. Cleburne Living Cent., 473 U.S. 432, 455 (1985) (Stevens, J., concurring) ("I cannot believe that a rational meinber of this disadvantaged class could ever approve of the discriminatory application of the city's ordinance in this case."); Okin, Reason and Feeling in Thinking About Justice, in Feminism AND Political Theory 15, $27-30$ (C. Sunstein ed. 1990) (discussing original position as requiring people to "think from the point of view of everyone"). An excellent example of anti-caste legislation is the Violence Against Woinen Act, see 136 CoNG. Rec. S8263 (daily ed. June 19, 1990), whicl contains various measures designed to reduce and reinedy gender-related violence. Sucl a measure cannot easily be understood in compensatory terms; and it could not be initiated by courts. 
into doubt unconscious discrimination as well as selective empathy and indifference on the part of those who created the practice; and the answer will frequently be negative. Of course, there will be severe difficulties in administering a system built on a question of that sort. But this is the best inquiry in this context.

I do not suggest that a principle of this sort leads to a particular specification of substantive rights or institutional arrangements. It needs to be supplemented with a range of other considerations in order to become a plausible basis for civil rights policy. It does, however, have several implications by itself. It suggests that compensation for past wrongs is not the guiding principle for civil rights pohicy; compensation and restoration of the status quo are not the basic issues at all. It suggests that often, discrimination fueled by factors other than prejudice or irrationality is also the target of civil rights policy, because of the consequences of those forns of discrimination for the relevant group. It suggests that a system with sufficient opportunities for education, training, or einployment, without race- and sex-related violence, and without incentives for teenage childbearing or participation in crime, is a principal goal of civil rights policy. It suggests, finally, that the elaboration and impleinentation of the relevant poticies should be undertaken, at least in the first instance, by legislative and executive bodies and not by the courts. In all these respects, this principle represents a renovation of all that lias guided civil rights policy over the last generation.

\section{CONCLUSION}

I liave suggested that three of the principal claims that underlie civil riglits law and policy are in important respects fallacies. Discrimination is not always the product of prejudice or irrationality. Moreover, to understand the antidiscrimination principle im compensatory teruns leads to questions that are unanswerable. Finally, reliance on constitutional adjudication is a large imistake for civil riglits law.

The three fallacies fit well together. Each of them fortifies the others. The coinpensatory principle is well adapted to reliance on judicial institutions. The notion that discrimination is a product of prejudice or irrationality also lielps to promote reliance on the courts, enabling them to build antidiscrimination principles on the foundations of tort law. But if discrimination cannot be well understood in these ternns, all the fallacies must yield. They provide a poor foundation for civil rights law and practice im the coming generation.

I lave also suggested, though more tentatively, that civil riglits law should be inforined by a principle that forbids morally irrelevant differences froin being turned, witliout very good reason, into a systemic source of social or legal disadvantages. Thus understood, the 
antidiscrimination principle becomes an anti-caste principle. To be sure, elaboration of that principle is a large task, one that leaves open a wide range of questions concerning both substance and institutional arrangements. But if I am correct, such a principle provides a better foundation for civil rights policy than the three fallacies that have burdened the law for so long. 